Instructions for authors, subscriptions and further details:

http://ijep.hipatiapress.com

\title{
Essentials of Human Memory
}

Carmen Martín Gómez ${ }^{1}$

1) Universidad Loyola Andalucía, Spain.

Date of publication: February $24^{\text {th }}, 2016$

Edition period: February 2016 - June 2016

To cite this article: Martín Gómez, C. (2016). [Book Review of the book Essentials of Human Memory by Alan Baddeley] International Journal of Educational Psychology, 5(1), 108-110. doi: 10.17583/ijep.2016.1909

To link this article: http://dx.doi.org/10.17583/ijep.2016.1909

\section{PLEASE SCROLL DOWN FOR ARTICLE}

The terms and conditions of use are related to the Open Journal System and to Creative Commons Attribution License (CC-BY). 
IJEP - International Journal of Educational Psychology, Vol. 5 No. 1 February 2016 pp. 108-110.

\section{Review}

Baddeley, A. (2014). Essentials of Human Memory. Hove: Psychology Press

Alan Baddeley, a psychologist from the University of York, well known for his research focused on the working memory, invites us to know the most relevant scientific knowledge on learning and human memory in this rigorous work from an easy to understand approach.

He begins showing us how different authors have described memory throughout history: William James in 1890 or Donal Hebb in 1949 had already proposed that the human memory consisted of a system formed by sub-components. In 1968, Atkinson and Shiffrin presented The modal model, a memory system with 3 different components: sensory registers (visual, auditory or haptic), short-term memory (STM) and long-term memory (LTM). Derived from an experiment aimed at showing the defects of STM, Graham Hitch and Baddeley (1974) proposed that working memory had three components: central executive, phonological loop and visualspatial sketch pad. On the other hand, in 1972, Tulving proposed two different types of long-term memory: semantic and episodic. After that, in 1984, Hudson led a research carried out with children that revealed that the development of both types of LTM was produced interactively.

The author also talks about the two main paradigms in which the research on human memory has been focused on for the last 100 years. The first one, which was initiated by Ebbinghaus, is characterized by very simple memory tasks and well-controlled conditions. The second one, which was introduced by Barlett, appeared to refute the previous paradigm, and it is characterized by using rich and meaningful materials in memory tasks, such as stories and pictures, under natural conditions. This last approach derived in studies as the one led by Luria with Shereshevskii, a mnemonist. 


\section{Martín-Essentials of Human Memory [Book Review]}

Furthermore, Baddeley explains processes such as forgetting, which is represented by the forgetting curve (Ebbinghaus, 1885), or the concept of repression, which was introduced by Freud and refers to forgetting painful memories.

Baddeley also discusses memory from a perspective of age. On the one hand, he explains the childhood memory, focusing on episodic memory and showing, through different studies, how the child's autobiographical memories evidence that they learn explicitly. Moreover, the book presents scientific evidence from the research on memory and ageing, showing that there is deterioration in working memory and long -term memory, among others, whereas the vocabulary improves the older a person is. Within the same chapter, the author provides an extensive explanation of Alzheimer's disease.

The author also explains different types of amnesia giving examples that define its causes and explains that people with amnesia can continue learning as the famous patient H.M.

The importance of this book for educational psychology lies in the fact that the author makes reference to the learning process all time throughout the book, giving us information to be taken into consideration, both to investigate in learning in educational psychology and to translate such memory research into the practice of instruction. Some of the most remarkable messages in this regard can be summarized as follows: The scientific study of memory and learning starts in 1880 by the hand of Ebbinghaus, who demonstrated that it was possible to study the human memory from an empiric paradigm through his own learning. He discovered the Total Time Hypothesis, on which the human learning is based. From a neurophysiological approach, memory and learning processes produce a sequence of changes in the brain of electrophysiological and neurochemical nature. For example, Eric Kandel (2006) showed this in some simple learning processes such as habituation, sensitisation and classical conditioning, in Aplysia, a marine organism. In more complex aspects of learning, the long-term potentiation (LTP), a mechanism where they are involved cells related to learning and memory has been proposed. Some evidence has demonstrated that the phonological process, memory and learning to read are connected. It means that memory development is involved in educational processes. 
At the end of the book, Baddeley gives us his prospective about future research interests on human memory and explains how the study of memory is becoming interdisciplinary, how cognitive psychologists are beginning to work with colleagues from other fields such as neurology, neuroradiology, clinical medicine and social psychology, among others, and he predicts that the study of memory will continue to be active.

\section{References}

Atkinson, R.C. \& Shiffrin, R.M. (1968). Human memory: A proposed system and its control processes. In K.W. Spence \& J.T. Spence (Eds.), The psychology of learning and motivation: Advances in research and theory. (Vol. 2). (pp. 742-775). New York: Academic Press.

Baddeley, A. D., \& Hitch, G. J. (1974). Working memory. In G. A. Bower (Ed.), The psychology of learning and motivation: Advances in research and theory. (Vol. 8, pp. 47-89). New York: Academic Press.

Ebbinghaus, H. (1885). Memory: A contribution to experimental psychology. New York: Dover.

Kandel, E. (2006). In search of memory The emergence of a new science of mind. New York: W.W. Norton \& Company.

Tulving, E. (1972). Episodic and semantic memory. In E. Tulving and W. Donaldson (Eds.), Organization of Memory (pp. 381-402). New York: Academic Press.

Carmen Martín Gómez Department of Psychology Universidad Loyola Andalucía cmartin@uloyola.es 